\title{
ANALÍTICA DE LA EUFORIA Y LA IRA. EL GOBIERNO DE LAS PASIONES EN EL CAPITALISMO CONTEMPORÁNEO
}

\author{
Alejandro Recio Sastre \\ Universidad de Valladolid y Universidad de Chile \\ alejandrorecio13@gmail.com
}

\begin{abstract}
RESUMEN / ABSTRACT
Actualmente, la euforia y la ira deambulan entre las multitudes como oscilaciones ambiguas de miedo y esperanza, pasiones que, en aquella ya lejana modernidad del barroco, Spinoza catalogó como fluctuaciones del ánimo provocadas por afectos inconstantes de alegría y tristeza. Durante el desarrollo del capitalismo, el miedo y la esperanza dejaron de ser pasiones efectivas para llevar a cabo el gobierno de las masas. Ambas fueron reemplazadas por la euforia y la ira, segmentaciones de frecuencias afectivas que dominan los flujos sociales con el propósito de obtener mayores rendimientos en la concentración de capital.

PALABRAS ClaVE: pasiones, ira, euforia, fluctuaciones, composiciones de afectos, consumo, multitudes, frecuencias afectivas, flujos sociales.
\end{abstract}

\section{EUPHORIA AND ANGER ANALYTICS. THE GOVERNMENT OF THE PASSIONS IN CONTEMPORARY CAPITALISM}

Nowdays the euphoria and the wrath wander around between the crowds like ambiguous oscillations of fear and hope, passions that in the far modernity of the baroque, Spinoza classified how fluctuations of moodtriggered by inconstant affective of joy fulness and sadness. During capitalism's development the fear and the hope left to be effective passions for carrying out the steering of the masses. Both werere placed by the euphoria and the wrath, segmentations of affectives frequencies that dominate the socialflows with the objetive of getting higheryields in the capital concentration.

KEYWORDS: Passions, wrath, euphoria, fluctuations, compositions of affects, consumption, crowds, affectfrequencies, socialflows.

\section{Frecuencias segmentadas, afectos inconstantes}

RR Durante los años sesenta y setenta del siglo XVII, entre los intervalos más distendidos de una vida errante dedicada a la construcción de lentes, Spinoza escribía una de sus obras más prolíficas, la Ética demostrada según el orden geométrico.

1 Dirección Postal: Calle Jesús Arambarri. Número 95, letra D. Salamanca (España). Código Postal: 37003. 
En esta obra, el pensador sefardí le prestó especial atención a la cuestión de los afectos humanos y su repercusión en la vida humana. Según Gilles Deleuze, la noción de vida en Spinoza no debe comprenderse como una cuestión teórica, ya que la vida es más bien "una forma de ser, un mismo y eterno modo en todos los atributos. Y es solo desde este punto de vista desde el que adquiere todo su sentido el método geométrico" (Deleuze 2006, p. 22).

Spinoza distingue las ideas de la imaginación de aquellas que tienen que ver con el entendimiento. La indisoluble unidad del ser es una cuestión de entendimiento porque solo a la razón le compete pesquisar los atributos infinitos de Dios (Spinoza 2000, p. 49). Cuando los seres humanos conciben a la materia desde la imaginación, ven los cuerpos como entidades limitadas y divisibles, pero cuando la materia es concebida desde la razón, los objetos naturales ya no pueden ser excluidos de la sustancia divina (ibidem, p. 50-51). Quienes juzgan las cosas solo en función de su imaginación ignoran la verdadera naturaleza de todo lo existente, pues solo los ignorantes creen que las cosas existen con arreglo al modo en que les afectan, sin reparar lo suficiente en pensar de cuántas formas diversas puede ser afectada la imaginación (ibidem, p. 72).

Los individuos son afectados por un flujo constante de afecciones corporales que incrementan o disminuyen sus aptitudes. Las acciones son afecciones causadas por nosotros mismos, mientras que las pasiones se derivan de afectos no causados por nosotros, o sea, afecciones exteriores a nuestra capacidad de actuar y que, por tanto, padecemos (ibidem, p. 126-127). Conviene poner de relieve la diferencia entre afecto y afección a partir de la interpretación realizada por Deleuze en sus lecciones sobre Spinoza: dicha diferencia está en que un afecto es "la variación continua de la fuerza de existir, en tanto que está determinada por las ideas que se tienen" (Deleuze 2003, p. 172) y la afección "es el estado de un cuerpo en tanto que sufre la acción de otro cuerpo" (ibidem, pp. 173-174). El propio Spinoza reconoce que la acción de los cuerpos exteriores sobre la corporalidad humana solo genera ideas inadecuadas o confusas debido a que el alma solo puede dar cuenta del estado del cuerpo vivo que integra, así que la naturaleza de los cuerpos exteriores no puede ser dilucidada. Solo en la medida en que las afecciones aumentan o disminuyen la potencia de actuar y de existir, las ideas son adecuadas o no a los objetos. La excelencia de los objetos se determina merced a tres afectos: la alegría, la tristeza y el deseo (Spinoza 2000, pp. 179-180).

La concatenación de las cosas en la naturaleza y la concatenación de las afecciones en el alma humana es una sola, de modo que el alma y el cuerpo están unidos necesariamente, pero su unión, ni es parcial ni es una síntesis de partes diferenciadas, sino que, más bien, ambos conforman una misma cosa. Ya sea bajo el atributo del pensamiento, ya sea bajo el de la extensión, las acciones y las pasiones se dan en la simultaneidad cuerpo-alma (Spinoza 2000, p. 128). La esencia del alma es la idea del cuerpo en acto. Cuando el alma se encuentra en sintonía con la esencia activa del cuerpo, las ideas son adecuadas, mientras que, cuando el alma padece, tiene ideas inadecuadas (ibidem, p. 131).

No todos los objetos afectan de la misma manera al cuerpo, ni en todos los momentos un mismo objeto puede afectar de una misma forma la corporalidad, e inversamente, 
las cosas no siempre son afectadas del mismo modo por el cuerpo (ibidem, p. 139). Spinoza afirma que como es muy frecuente que quienes han experimentado muchas cosas, al contemplar una cosa como futura o pasada, fluctúen y duden sobremanera de su acontecer, resulta que los afectos que surgen de semejantes imágenes de las cosas no son tan constantes, sino que son alterados por imágenes de otras cosas, hasta que los hombres se cercioran del resultado de la cosa (ibidem, p. 140).

Cabalmente puede interpretarse que la noción spinozista de afección hace referencia a frecuencias producidas por la concatenación de cosas y afectos, de tal forma que cuando los seres humanos se ven afectados por la duda, aparecerá una retención del flujo constante con que se desarrollan las actividades vitales, es decir, toda fluctuación generada por la duda restringirá las acciones que se coordinan en la unidad cuerpo-alma. Si la duda hace vacilar al alma, padecemos; si el cuerpo no encuentra aptitud para hacer algo, es impotente. Por tanto,--de acuerdo con la interpretación que viene proponiéndose- las pasiones serán afectos que se propagan con una determinada frecuencia en la vida, de tal modo que aquellos afectos que prolongan la capacidad de producir afecciones generarán frecuencias constantes en la disposición de actuar, pero aquellos afectos que intersectan y segmentan la frecuencia con que los sujetos pueden producir afecciones causarán pensamientos volátiles y harán la imaginación más susceptible de dominio. Asimismo, en relación con esta caracterización de las pasiones en general, la esperanza y el miedo aparecen respectivamente como una alegría y una tristeza inconstantes, cuyo surgimiento se da a partir de imágenes pasadas o futuras de dudosa efectuación (ibidem, p. 140).

La esperanza y el miedo producen una inconstancia en la frecuencia con que se desarrollan las afecciones, hacen fluctuar el ánimo, y toda fluctuación supone una interrupción en cualquier tipo de flujo constante. Remo Bodei afirma que, en el momento de su duración, "miedo y esperanza dominan no solo el cuerpo, sino la imaginación y la mente de los individuos, dejándolos a merced de la incertidumbre y volviéndolos dispuestos a la renuncia y a la pasividad" (Bodei 1995, p. 76). A ojos de Bodei, en la política de Spinoza la multitud oscila entre el miedo y la esperanza de manera pendular, pues la multitud se ve expuesta a inquietudes permanentes que la mantienen fluctuando incesantemente. Pero la volatilidad de las masas impide una gobernanza estable, puesto que el gobierno no puede trazar una trayectoria constante sobre una multitud siempre en estado variable. La multitud tan pronto puede aparecer sumisa como insumisa, la multitud es impredecible, especialmente en las situaciones críticas (ibidem, pp. 300-301).

La conjugación pasional del miedo y de la esperanza tiene importantes repercusiones políticas, dado que ambas pasiones se apoderan de las fuerzas masivas, esas mismas fuerzas con que un régimen político puede perpetuarse o cambiar. Pero miedo y esperanza no implican la dicha de los seres humanos ni eleva la vida a una mayor dignidad. "La mayoría de los hombres experimentan una existencia por debajo de las propias posibilidades abstractas, transcurren una vida fallida, deteriorada por el miedo y por la esperanza, envenenada por la superstición y por la atracción por la muerte" (ibidem, p. 305). 
En el pensamiento de Spinoza, las composiciones de afectos se corresponden con la inmanencia de la que surgen primariamente el deseo, la alegría y la tristeza (Spinoza 2000 , p. 223). Los afectos primarios representan nociones comunes y no un simple sustrato. El contenido variable de las relaciones que conectan la inmanencia afectiva con las causas externas produce las composiciones de afectos. Asimismo, el deseo, la alegría y la tristeza no serían más que abstracciones que definen las transiciones variables de las múltiples composiciones afectivas que pueden surgir (Morfino 2014, p. 37). A este respecto, tanto Vittorio Morfino como Deleuze coinciden en que el encuentro define la noción de pasión en Spinoza: para Morfino, el autor nos conduce "al primado de lo aleatorio sobre toda teología o teleología de la causa, o mejor dicho, al primado del encuentro sobre la forma" (Morfino 2014, p. 38), para Deleuze, aunque el pensador sefardí solo utilizó una vez la palabra occursus, traducida como "encuentro", este término nos sitúa ante la interpretación de las ideas-afecciones como vivir "al azar de los encuentros" (Deleuze 2003, p. 175). Puede que algo nos satisfaga más o menos, podemos sentir los afectos con alegría o con tristeza, pero lo cierto es que todos ellos se producen como encuentros, es decir, tienen lugar dentro de una relación.

El carácter relacional de las pasiones conforma los contenidos afectivos que el capitalismo, a lo largo de su historia, ha tratado de apropiarse con mayor o menor éxito -en las últimas décadas con demasiado éxito-. El capitalismo ha perfeccionado las estrategias de "servidumbre voluntaria", aquellas que Frederic Lordon vincula con el desarrollo del pensamiento "individualista-subjetivista", que prima lo voluntario como ejercicio de soberanía sobre sí mismo y que incluso admite la servidumbre si es preferida por el sujeto. Esta manera de pensar fue la que -a ojos de Lordon-Spinoza rechazó, pues dentro de su filosofía no hubo cabida para la servidumbre voluntaria, dado que "las verdaderas cadenas son las de nuestros afectos y nuestros deseos" (Lordon 2015, p. 37).

En el contexto capitalista actual, la tensión ambivalente de frecuencias tristes y alegres en relación con el deseo marca el balance del miedo y la esperanza, ya que, por un lado, el deseo de incrementar el beneficio salarial aparece como una alegría que invita a trabajar, una alegría inconstante, y por otro lado, las condiciones de trabajo para acceder al salario implican un temor producido por afectos tristes. Aunque los afectos tristes sean combatidos por los sujetos incrementando su potencia de actuar, los afectos tristes continúan estando presentes cuando la acción no se adecua a la potencia (Spinoza 2000, p. 136). En un ambiente de completa dominación y de condicionamientos ineluctables dentro del entorno económico, los individuos se ven siempre abocados a la violencia en sus relaciones con los otros, pues estimulan su alegría con la desdicha ajena (Lordon 2015, pp. 44-45). La contención de esta violencia dentro de los límites prescriptivos del mercado, así como la competencia en general, trastoca las inconstantes frecuencias afectivas de miedo y esperanza. La violencia retenida genera ira, pero los impulsos agresivos y competitivos son desviados a través de segmentos afectivos de euforia, insuflados en contextos de júbilo y ociosidad, en los que existe la posibilidad relativa de acceder a bienes, servicios y formas de vida. 


\section{De la esperanza y el miedo a la euforia ${ }^{2}$ la ira}

El paso de la esperanza y el miedo a la euforia y la ira no debe ser entendido exactamente como una transformación, es decir, como un cambio transitivo de un estado pasional a otro; ni tampoco ha de ser entendido como una sustitución de pasiones articulada en una línea transitoria nítida y bien definida. No. El paso de la esperanza y el miedo a la euforia y la ira se corresponde con una dosificación de las composiciones afectivas que hacen fluctuar el ánimo de las multitudes, superando los parámetros de gobernanza utilizados en el pasado.

El declive de la esperanza y el miedo como pasiones instrumentales para el gobierno de las multitudes no fue solventado en los siglos posteriores a la caída de los regímenes absolutista-teológicos. Con la disolución política y social del Antiguo Régimen y el auge del capitalismo, el miedo y la esperanza continuaron produciendo fluctuaciones del ánimo en la muchedumbre, es más, la política moderna no encontró resolución posible a estas fluctuaciones masivas, tan solo prolongó el declive de los viejos instrumentos pasionales de gobernanza. Ergo, las alteraciones sociales causadas por las crisis capitalistas reproducían de nuevo esos mismos movimientos inconstantes propios de la etapa absolutista, pero, en este caso, tales movimientos no traían consecuencias positivas para la perpetuación del régimen de producción, propiedad y gubernamentalidad capitalistas.

2 La Real Academia Española (RAE) le atribuye a la palabra "euforia" las siguientes definiciones: "1. Entusiasmo o alegría intensos, con tendencia al optimismo. 2. Sensación exagerada de bienestar que se manifiesta como una alegría intensa, no adecuada a la realidad, acompañada de un gran optimismo" (ver en: http://dle.rae.es/?w=euforia). De acuerdo con la segunda acepción, podríamos resaltar el carácter spinozista que de forma fortuita y casual la RAE le ha concedido al término "euforia", al considerar que es un sentimiento de alegría intensa inadecuado a la realidad. Aunque Spinoza no le atribuyó una definición concreta a la euforia en su "definición de los afectos" (ver en Spinoza 2000, pp. 169-180), ni hizo un tratamiento explícito de esta, sí es importante para el porvenir del presente artículo aprovechar la definición que hace la RAE en vistas a extraer una noción de euforia como idea inadecuada, lo que la convierte en pasión, y solo de este modo se justifica su inclusión en el inventario de pasiones que Spinoza inició tan minuciosamente y con tan alto grado de rigor.

3 Spinoza define la ira como "el deseo que, por odio, nos incita a que inflijamos un mal a aquel a quien odiamos" (Spinoza 2000, p. 177). La novedad de la ira contemporánea como pasión instrumental para el ejercicio del gobierno se debe al grado de inconstancia e inacción que la acompaña. Mediante dosificaciones muy puntuales, por ejemplo, a través de hostigar y vapulear verbalmente a ciertas personalidades, actividades culturales, creencias, costumbres o ideologías en los medios de comunicación, se insufla ira en las conciencias. La ira en la actualidad ha de propagarse mediante un odio sesgado cuya duración está expuesta al criterio de instancias o individuos ajenos a quien padece esta pasión. Estamos hablando de una ira contenida pero que produce estados de opinión pública e imaginarios sociales susceptibles de generar conductas y reacciones. 
Desde la etapa decimonónica, el miedo y la esperanza ya no aparecían como pasiones teológicas, ni respondían a la articulación de prejuicios y códigos en general del absolutismo: ni el miedo a un castigo celestial ni la esperanza en una salvación de ultratumba podían agitar o perturbar el ánimo social como antes. Es más, en las sociedades capitalistas el cauce de miedos y esperanzas ${ }^{4}$ provenía de un ambiente mucho más cotidiano, terrenal y deliberadamente económico; así, la concentración del poder estatal, la posibilidad de una quiebra económica, el desempleo, amén de la avidez de enriquecimiento o la consecución del derecho de acceso a determinados servicios son solo algunos ejemplos del heterogéneo espectro de expectativas que afectaban a la multitud.

Antes de que el neoliberalismo pusiera "a la sociedad y la democracia en línea con la valorización capitalista [...]" y de que produjera "una gubernamentalidad autoritaria posdemocrática" (Lazzarato 2013a, p. 112), no hubo dentro del sistema capitalista una gubernamentalidad capaz de controlar los desbordes pasionales de las multitudes afectadas por el miedo y la esperanza. De hecho, la composición afectiva del miedo y la esperanza fuera de los códigos de gobierno absolutistas y dentro de un horizonte postfeudal causó importantes desastres políticos para los intereses asociados a la acumulación de capital y, además, contusionó gravemente a las sociedades. Las esperanzas que suscitaron los líderes fascistas (con promesas sociales y a la vez belicistas apoyadas en la base de un eufórico amor a la grandeza de la nación y la raza), las esperanzas enarboladas por las ideologías izquierdistas, las esperanzas en un gobierno redentor que redistribuyera la riqueza y acabara con el desempleo y, paralelamente, los miedos raciales o los miedos asociados a la pobreza, como también el miedo de la mayoría social a las inclemencias y situaciones miserables provocadas durante los periodos de crisis económica, dan buena cuenta de hasta qué punto la desatención de la dimensión subjetivo-afectiva de las multitudes implicaba el despropósito político para las élites capitalistas y muy a menudo también el cataclismo y la devastación para la población. Había que controlar la capacidad de desborde del miedo y de la esperanza, dominar sus bruscas oscilaciones e imprevisibles fluctuaciones. No se trataba de anular el miedo y la esperanza como afectos nocivos para el gobierno de la multitud, por el contrario, había que rencauzar sus frecuencias afectivas mediante segmentaciones que controlaran los ritmos crecientes y decrecientes de la sociedad; todo ello para evitar que las fuerzas afectivas inmanentes a la multitud agitaran tumultos revolucionarios o encaramaran gobiernos incontrolables para el capital.

Solventar el descontrol de las composiciones afectivas requería que el capitalismo neoliberal utilizara la exposición de productos y actividades en televisiones, redes sociales, malls, etc., como cuadratura de dominio sobre las frecuencias afectivas.

4 Cabe recalcar que hablar de "miedo" y "esperanza" en plural pretende zafarse de la referencia a un solo símbolo de contenido pasional, a saber, la referencia a un solo Dios, a un solo Estado, a un solo rey, etc. Los objetos de las pasiones teológicas han sido reemplazados por asuntos referidos a aspectos múltiples que forman parte de las relaciones en el mundo globalizado. 
Todo se convierte en objeto de consumo y todas las oscilaciones afectivo-masivas habrán de resultar favorables a la acumulación de capital. El carácter embaucador de la publicidad produce una euforia individualizada y despreocupada que solo se masifica cuando los cuerpos "coinciden" en los espacios mercantiles. La euforia solo puede verse alimentada por la producción del espectáculo. La muchedumbre consumidora arrastra a los individuos a través de las oscilaciones calculadas en los juegos de espectacularidad. Guy Debord afirma:

El espectáculo somete a los hombres vivos en la medida que la economía les ha sometido totalmente. No es más que la economía desarrollándose por sí misma. Es el reflejo fiel de la producción de las cosas y la objetivación infiel de los productores (Debord 2007, p. 28).

En la sociedad del espectáculo todas las cosas terminan convirtiéndose en mercancía, incluso el tiempo, puesto que el tiempo aparece en el mercado diversificado en múltiples productos susceptibles de consumición (Debord, 2007, p. 103). La mercancía domina las relaciones sociales a través del espectáculo. El tiempo espectacular es inconstante, de modo que las pasiones que produce se desarrollan a través de frecuencias afectivas segmentadas. La ira y la euforia son las segmentaciones afectivas por excelencia de la temporalidad mercantilizada, propias de un tipo de vida embelesada por las imágenes de las mercancías, refracciones estériles de una existencia maleable y enajenada.

Los individuos se valoran entre sí y para sí con arreglo a la cantidad de mercancías que pueden adquirir mediante el dinero. Entonces, en el mundo gobernado por el espectáculo de la mercancía, los sujetos valen tanto como el dinero que pueden acumular o mantener, solo así alcanzarán las seguridades necesarias para sobrevivir en medio de un mundo competitivo y repleto de obstáculos interpuestos por los otros. Mas, no por ello, los individuos logran una identidad o compromiso profundo consigo mismos y con los demás. Como dice Byung-Chul Han al respecto:

El dinero es un mal transmisor de identidad. Sin embargo, puede reemplazarla, pues el dinero proporciona a quien lo posee al menos una sensación de seguridad y de tranquilidad. Por el contrario, quien ni siquiera tiene un poco de dinero no tiene nada: ni identidad ni seguridad. Así, forzosamente se evade a lo imaginario, por ejemplo, a la idiosincrasia de un pueblo, la cual pone rápidamente a disposición una identidad. Al mismo tiempo se inventa un enemigo, por ejemplo, el islam. Es decir, a través de unos canales imaginarios levanta unas inmunidades para alcanzar una identidad que otorga sentido. El miedo por sí mismo hace que inconscientemente se provoque la nostalgia de un enemigo (Han 2017, pp. 12-13).

El miedo y la nostalgia de un enemigo se combinan para dar paso a un segmento afectivo de ira, una ira que solo puede ser domeñada mediante la inyección temporal o permanente de dinero. Pero la inyección de dinero no está exenta de frecuencias tristes y temores producidos durante el tiempo de trabajo. "La dirección por el estrés" (Cohen 2013) practicada en las empresas capitalistas del presente, según la teoría económica neoliberal, anima la competencia interna entre los trabajadores, que se remiten a mantener su empleo como único incentivo. Entre los avatares del mundo laboral y su 
insufrible inestabilidad, la ira va solidificando una poderosa cuadratura dentro de las composiciones de afectos, llegado el momento, cualquier enemigo imaginario puede convertirse en blanco de odio iracundo, aunque nada tenga que ver con la situación incierta y triste de los pesares en el trabajo. Esa ira sale a flote en contextos donde la euforia frustra las propias expectativas que ha generado.

La euforia viene producida por la dosificación de esperanzas segmentadas a través de la que operan frecuencias alegres muy intermitentes e intensas, el control de las frecuencias eufóricas requiere de todo tipo de mercancías espectaculares, de tal modo que los ritmos inconstantes del consumo coinciden con las frecuencias segmentadas de euforia. Pero la inaccesibilidad a estas mercancías espectaculares, la imposibilidad de experimentar el espectáculo debido a la ausencia de dinero sedimenta unos miedos cuya manipulación solo puede expresarse en segmentos de ira, una ira contenida en las cuadrículas políticas del "odio al otro" por razones de raza, ideología, clase social, sexo, etc. De este modo, euforia e ira se hallan íntimamente ligados, puestos que forman parte de una misma segmentación de frecuencias afectivas. Al igual que para Spinoza no puede haber esperanza sin miedo ni miedo sin esperanza (Spinoza 2000, p. 159), tampoco puede haber euforia sin ira ni ira sin euforia. Cabe preguntarse al respecto: ¿cómo enhebra el capitalismo actual el nódulo fluctuante entre la euforia y la ira a partir de los reflujos de la composición afectiva esperanza-miedo?

\section{Creación de necesidades y apariencias de libertad}

Marcuse catalogó las necesidades humanas en dos bloques: las verdaderas y las falsas. Las necesidades verdaderas son aquellas que satisfacen biológica y fisiológicamente a los individuos, son necesidades que hay que cubrir a la fuerza para mantener la vida corporal y hacerla mínimamente saludable ${ }^{5}$. El otro bloque de necesidades, las falsas, viene impuesto por intereses sociales particulares, cuya satisfacción es relativa al ordenamiento superfluo de actividades y cosas supuestamente gratificantes. La característica más significativa de las necesidades falsas es que son producidas por poderes externos al control de los individuos, por lo que su producción y también su satisfacción son heterónomos (Marcuse 1968, p. 27).

Según Marcuse, únicamente individuos libres podrían dar respuesta a cuáles son las necesidades verdaderas y cuáles las falsas, pero esto solo pueden hacerlo individuos que gozan de autonomía y, por ende, de libertad para decidir. Sin embargo, los individuos se acogen a juicios sobre sus propias necesidades que son ajenos a su libre disposición y capacidad de autodeterminación. Si bien resulta loable oponerse a la presencia de una instancia o tribunal que atribuya mayor prioridad a unas necesidades con respecto a

5 "Las únicas necesidades que pueden inequívocamente reclamar satisfacción son las vitales: alimento, comida y habitación en el nivel de cultura que esté al alcance. La satisfacción de estas necesidades es el requisito para la realización de todas las necesidades, tanto de las sublimadas como de las no sublimadas" (Marcuse 1968, p. 27). 
otras, sucede que en las sociedades industriales avanzadas hay necesidades que podrían ser liberadas. Los individuos pueden elegir entre una colección de cosas que se les presentan en el mercado, así como también en el terreno político pueden seleccionar a distintos gobernantes, pero, pese a ello, Marcuse no considera que la libertad se restrinja a la libre elección de cosas y gobernantes, puesto que tras el abanico de posibilidades elegibles existen factores condicionantes e intereses ajenos configurados previamente (Marcuse 1968, pp. 28-29).

La libre elección de amos no suprime ni a los amos ni a los esclavos. Escoger libremente entre una amplia variedad de bienes y servicios no significa libertad si estos bienes y servicios sostienen controles sociales sobre una vida de temor y de trabajo, esto es, si sostienen la alineación. Y la reproducción espontánea, por los individuos, de necesidades superimpuestas no establece la autonomía; solo prueba la eficacia de los controles (ibidem, pp. 29-30).

El capitalismo abanderado por el neoliberalismo reduce toda concepción de libertad a la mera elección de amos, bienes, servicios, estilos de vida, posibilidades e ideas ya prefiguradas. El neoliberalismo sistematiza el concepto de una libertad aparente, una seudolibertad. Pero si esta seudolibertad fuera expresamente comunicada y los individuos tomaran conciencia de ella, el capitalismo neoliberal ya habría perdido todas las sutilezas en las cuadraturas de sujeción y en las operaciones de subjetivación que produce y aplica. Precisamente el neoliberalismo cuenta con capacidad suficiente como para ocultar tras bellos conceptos realidades devastadoras, incluida la seudolibertad que preconizan sus partidarios y divulgadores como si fueran los únicos pensadores e ideólogos adalides de la verdadera libertad.

Es imprescindible tener en cuenta la advertencia que Sloterdijk hace sobre la teoría crítica a propósito de la subjetivación, una advertencia que afortunadamente nos ayuda a refinar la exégesis del capitalismo actual. Sloterdijk le reprocha a la teoría crítica la concepción"de la subjetividad moderna como agencia de autocontrol, dicho psicoanalíticamente: la neurosis represiva" (Sloterdijk 2010, p. 79). El sujeto sloterdijkeano viene caracterizado por su imprevisibilidad, un actor que se hace confidente de sí mismo solo de cara a la acción, que conoce siempre y cuando encuentra una salida práctica para aquello que sabe. La subjetivación habilita para la acción, pero nadie puede saber qué ambiciones y finalidades atraviesan los pensamientos de esos sujetos prestos a actuar, de manera que todo sujeto es sospechoso de querer hacer algo, bien por razones proporcionadas desde una meticulosa meditación consigo mismo o bien por servidumbre a poderes configurados de forma anónima (ibidem, pp. 79-80).

El capitalismo neoliberal trata de controlar los márgenes de la acción condicionando la subjetividad. El sujeto es llamado a crearse a sí mismo mediante su actividad económica. Los estados de ánimo acompañan en paralelo a la acción, reducida a su mero carácter productivo o comercial, de modo que estos estados de ánimo colorean la bruta materialidad capitalista y su seudolibertad. El proceso de evaluación meditativa que el sujeto moderno hace frente a sí mismo extenúa o atenúa los afectos en función de la dinámica económica; el capital no tiene acceso directo a los procesos internos 
de la subjetividad, pero sí puede intervenirlos indirectamente mediante el control de las frecuencias afectivas.

Los controles sociales y su eficacia requieren de una segmentación de afectos mediante los que sostener la creencia y participación de los individuos en los procesos donde, supuestamente, están practicando su libertad. La posición paciente del sujeto en la producción de elementos elegibles no debe aparecer como un motivo de resignación, sino como un motivo de orgullo ante la independencia individual lograda. Sin embargo, la libre elección no siempre trae consigo resoluciones felices, la libertad de elección oscila entre afecciones inconstantes alegres y tristes, de la euforia sentida ante el éxito a la ira causada por el fracaso. Los "fracasados" están afectados en cuanto sujetos que tomaron malas decisiones, o sea, se afectan a sí mismos como pésimos usuarios de la libertad que creen ostentar. Cuando las decisiones conllevan buenos resultados, los individuos se inflan de vanagloria ante sus méritos personales y riquezas obtenidas, méritos y riquezas que les permitirán ascender en la escala social y acercarse un poquito más al estilo de vida de los privilegiados. El afecto suscitado por una mala elección genera ira y el de una buena, euforia.

El capitalismo actual produce hordas masivas de iracundos y eufóricos que se manifiestan en los medios sociales de comunicación, estos, "no fomentan la cultura de la discusión. A menudo los manejan las pasiones" (Han 2017, p. 49). Todos los afectos vividos en la interioridad se reproducen fuera de la dimensión subjetiva en forma de flujos masivos, estos devuelven los rendimientos financieros a los centros de acumulación de capital a cambio de intensidades espectaculares de corta e inconstante frecuencia, o sostienen el orden político de dominación mediante dosis limitadas de odio. La euforia consumista se intercala ambivalentemente con la ira del odio en el juego de frecuencias afectivas productoras de flujos sociales.

La corrección de los afectos que intervienen en los procesos electivos no se halla bajo la revisión subjetiva del sí mismo o la intersubjetividad discusiva, su evaluación no depende de actividades reflexivas conscientes y, por ende, predomina la heteronomía en la segmentación de las frecuencias afectivas que inducen las acciones. La posición paciente de los individuos resulta inmodificable, por tanto, la evaluación de las decisiones también está controlada por el flujo social de los afectos. El dominio de las composiciones de afectos se origina en el deseo, los deseos aparecen como matices de estos marcos policromáticos afectivos.

Spinoza define al deseo como "el apetito con la conciencia del mismo" (Spinoza 2000 , p. 134). Deleuze interpreta que la noción de deseo en Spinoza, al ser la conciencia del conato por el que los seres humanos perseveran en su existencia, es el conato que se ha vuelto consciente (Deleuze 2006, pp. 72-73). El deseo se eleva a grado consciente en la medida en que hay modos de pensar que no son ideas. Las múltiples determinaciones del conato son un modo de pensar y solo cuando esta determinación toma la forma de

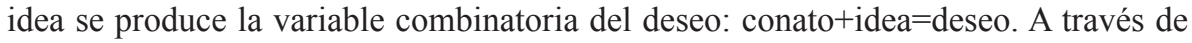
la lectura que hace Deleuze puede afirmarse que el deseo es aquella potencia afectiva que, partiendo de una inconsciencia primigenia, deriva en idea cuando uno mismo se sabe causa de sus propios pensamientos y llega a tomar conciencia de sus afecciones al 
hacerse una idea de algo que antes no contabilizaba en el orden de sus representaciones conscientes. Aunque el individuo sea y se perfile como causa de sus propias ideas, en el plano inconsciente operan potencias conativas capaces de producir frecuencias afectivas que mueven los flujos sociales de acuerdo con intereses ajenos a los sujetos, sin embargo, los individuos siguen creyéndose responsables y causantes únicos de sus pensamientos.

Los intereses son producidos por los deseos. Foucault afirma:

El deseo es la búsqueda del interés para el individuo. Por otra parte, aunque este pueda perfectamente ser engañado por su deseo en lo concerniente al interés personal, hay algo que no engaña: el juego espontáneo o, en todo caso, a la vez espontáneo y regulado del deseo permitirá, en efecto, la producción de un interés, algo que es interesante para la propia población. Producción del interés colectivo por el juego del deseo: esto marca al mismo tiempo la naturalidad de la población y la artificialidad posible de los medios que se instrumentarán para manejarla (Foucault 2004, p. 96).

Aunque Foucault no menta la palabra "necesidad", la producción del "interés colectivo" que surge de la articulación social del deseo podría interpretarse como una necesidad generada socialmente; de hecho, el modo en que Foucault concibe el "interés colectivo" podría equivaler fácilmente a la definición marcuseana de "necesidades falsas". Una necesidad falsa, en todo caso, es un interés creado de forma colectiva justo cuando el deseo que la sustenta deja de ser reprimido. Pero falta dar el paso definitivo para consumar la inversión necesidad-deseo, pues hay que echar a un lado términos como "interés colectivo" o "necesidades falsas" para referirse simplemente a las "necesidades" en cuanto carencias producidas dentro de la conjugación social de los deseos. No hay una conciencia directa de la necesidad, tan solo hay deseos a través de los que producimos las cosas que consideramos necesarias para nosotros; consecuentemente, los deseos pueden adecuarse o no al orden necesario que opera en el mundo (esta es la lección más decisiva que extraemos de Spinoza).

\section{El deseo productor y los límites internos y externos de la ira y de la euforia}

En El Anti-Edipo, Deleuze y Guattari consagran el deseo como productor de necesidades; dicen:

No es el deseo el que se apoya sobre las necesidades, sino al contrario, son las necesidades las que se derivan del deseo: son contraproductos en lo real que el deseo produce. La carencia de un contra-efecto del deseo está depositada, dispuesta, vacualizada en lo real natural y social. El deseo siempre se mantiene cerca de las condiciones de existencia objetiva, se las adhiere y las sigue, no sobrevive a ellas, se desplaza con ellas, por ello es tan fácilmente deseo de morir, mientras que la necesidad mide el alejamiento de un sujeto que perdió el deseo al perder la síntesis pasiva de estas condiciones (Deleuze y Guattari 1985, p. 34). 
Para Deleuze y Guattari, en el capitalismo el deseo se integra dentro del nivel de los flujos sociales, no en el de la ideología (ibidem, p. 247). El deseo está incrustado en los cortes que la maquinaria capitalista amplía en el intercambio de flujos de dinero, pues el capitalismo reproduce sus propios límites inmanentes (ibidem, pp. 246-247). El capitalismo es el límite inmanente de toda sociedad en cuanto que descodifica los flujos sociales, impone cortes en tanto en cuanto "sustituye los códigos por una axiomática extremadamente rigurosa que mantiene la energía de los flujos en un estado de ligazón al cuerpo del capital como socius desterritorializado, pero también e incluso más implacable que cualquier otro socius" (ibidem, p. 253).

La globalización como proceso extensivo de los axiomas del capital hacia todos los recovecos del planeta ha creado una maquinaria de descodificación y desterritorialización sin precedentes en la historia. Maurizio Lazzarato afirma que la globalización nunca habría sido posible sin la financiarización de la economía, el capital financiero, aunque dependiente del capital industrial y del capital comercial, se erige como forma de asignación del valor de las cosas, involucrando a toda la sociedad en los procesos de valorización e impidiendo la capacidad de influencia obtenidos por los obreros durante la hegemonía del capital industrial (Lazzarato 2013a, p. 153). El capital financiero ha difuminado la línea limítrofe que lo diferenciaba del capital industrial, ambos, ya no son realidades separadas. La axiomática del capital financiero gobierna la contabilidad de empresas públicas y privadas, toda gestión se convierte en un modo de gobernanza fundado y practicado según los cánones de esta axiomática, de manera que la economía real queda disuelta merced a las finanzas. Las directrices operativas de las finanzas copan todo aquello por lo que se define el quehacer económico (ibidem, pp. 154-155).

A pesar de que las civilizaciones modernas estén de facto descodificadas y desterritorializadas, "lo que por un lado desterritorializan, por el otro lo re-territorializan" (Deleuze y Guattari 1985, p. 265). La reterritorialización en el contexto de la globalización planteada por algunos movimientos políticos localistas y defensores del proteccionismo económico (Alt right, populismos, etc.) es una reterritorialización derivada de un marco axiomático que no se rebela directamente contra el capital, sino que busca conservar y reorientar la concentración de flujos financieros dentro de los núcleos locales y dentro de los márgenes políticos de la soberanía nacional, todo ello en medio de un mundo cada vez más competitivo y con una producción cada vez más deslocalizada. Si anteriormente las sociedades introducían códigos extraeconómicos allí donde la axiomática del capital había decodificado las relaciones sociales mediante el dinero, en la globalización los códigos resultan disfuncionales para la dinámica axiomática del capital financiero, de tal modo que "solo queda tomar en cuenta un dispositivo que se ocupe únicamente de relaciones funcionales (rentabilidad) entre sus elementos abstractos y no calificados" (Lazzarato 2013a, p. 156).

Las codificaciones soberanistas permanecen en el ostracismo debido a la rigurosa axiomática del capitalismo global, esta situación de aislamiento de los códigos extraeconómicos tan arraigados en los ambientes locales contribuye a intensificar la ira en aquellas poblaciones aletargadas por la competencia capitalista. El desamparo ante la inseguridad y la incapacidad para captar fuentes suficientes de financiación dispara la ira y, con ello, el límite social impuesto por el capitalismo global queda bajo 
amenaza. Mientras los afectos de ira permanecen recluidos fuera de las dinámicas de la financiarización, de la libre competencia mercantil y de la rentabilidad, las frecuencias de euforia funcionan a plena luz del día en el mundo globalizado en los mall henchido por consumidores en busca de novedades y precios oportunos. Pero las sociedades no están dirigidas por el intercambio, sino por potencias desiguales, las economías se organizan sobre la base de variables diferenciales de poder, de relaciones asimétricas (Lazzarato 2013b, pp. 86-87). Allí donde hay asimetrías en las relaciones de poder, también hacen acto de presencia las impotencias, porque los agentes que no pueden mantener una tensión en las relaciones de confrontación han de resignarse a la sumisión, y la ira es la expresión afectiva de su impotencia.

La ira se configura como un afecto extrínseco a los espacios abarrotados por los eufóricos consumistas, lo que no significa que esté fuera de control. La ira ocupa el lugar que Deleuze y Guattari le otorgaron a la esquizofrenia, a saber, el lugar inhibido por la axiomática del capital en cuanto su límite exterior (Deleuze y Guattari 1985, pp. 253-254). Además, en el límite social exterior, la ira solo puede internarse en la sociedad mediante frecuencias afectivas de euforia, motivando un estado de ambigüedad con respecto a esta. Ira y euforia se entrelazan para reterritorializar y codificar. La ira es el afecto de revancha que los perjudicados por la axiomática de la globalización abanderan.

El flujo iracundo suscitado por la resignación impotente en las relaciones de poder se canaliza en el segmento eufórico a través de la "voluntad de consumo". La voluntad de consumo suplanta todo tipo de voluntad que pretenda encabezar un poder de insubordinación. La fuerza política subyacente a la multitud es desintegrada por la individualización de la euforia consumista. Cuando la voluntad de consumo no puede alcanzar el objeto deseado, el segmento de la ira atrae los flujos que operaban en el segmento eufórico inventando un enemigo imaginario al que culpabilizar y atacar. Casi nunca la posibilidad de enfrentar las asimetrías es tomada en cuenta como una opción real, por lo que solo reina la resignación de quienes están persuadidos de su impotencia. En una sociedad que prima el rendimiento económico sobre el resto de aspectos de la vida cunde el cansancio entre los individuos, que padecen aisladamente los excesos de una producción inclemente mientras su semblante cansado se desvanece (Han 2012, p. 46).

Las dosis de euforia no pueden satisfacer a las masas afectadas por la impotencia; estas no permanecen frente al televisor o tras el escaparate de las grandes superficies impasibles, retorciéndose en su avidez insatisfecha. Pero el acceso a las cosas que se presentan como deseables ya no viene garantizado por el trabajo, por lo que"las raíces de la ira" (Castells 2017) brotan en la fragmentación de las naciones con respecto a las estructuras estatales y en la irreconciliable separación de las élites globales con respecto a las mayorías locales. Mientras la economía global y la práctica política continúen trazando alianzas, las fisuras de la democracia liberal cada vez serán más gruesas.

La ira, lejos de ser incontrolable, es aprovechada políticamente, no para codificar la sociedad desde fuera de la axiomática económica, sino para introducir nuevos elementos de valor económico en las relaciones humanas: la construcción de muros contra los flujos migratorios y las medidas proteccionistas son puestas en práctica recurriendo fundamentalmente a razones económicas, prescindiendo de los códigos éticos y legales. 


\section{Sintonización de frecuencias para el domino de los flujos sociales}

En el capitalismo de las sociedades occidentales se han intensificado los rendimientos en el proceso de acumulación y concentración de capital. A lo largo de los primeros quince años del presente siglo, la distribución ingresos/trabajo, por un lado, y la acumulación de capital, por otro, arroja los siguientes datos: un 10\% de personas ingresa entre el $25 \%$ y el $30 \%$ de los ingresos totales del trabajo y el $10 \%$ de poseedores con niveles de capital más alto abarca más del 50\% del total de capital; mientras tanto, el 50\% de trabajadores menos remunerados puede llegar a captar una cuarta parte o incluso un tercio del total de los ingresos, igualando con ello a la décima parte de los trabajadores mejor pagados; sin embargo, este $50 \%$ de trabajadores no llega a poseer el $10 \%$ del capital y, muy a menudo, ni el 5\% (Piketty 2014, pp. 267-268). Estos datos hacen ostensible una incesante concentración de capital en un sector muy concreto de la sociedad, amparado por una estructura económica con diferencias cada vez más pronunciadas.

La concentración de capital dirige los flujos sociales mediante frecuencias afectivas insufladas comunicativamente; así, la maquinaria concentracionaria capitalista tiene que mantener los ritmos de acumulación de capital por medio de las fluctuaciones de flujos sociales que le sean favorables. La aglomeración de los movimientos migratorios y la afluencia de consumidores son fenómenos paralelos a la concentración de capital. Cuanto más capital es acumulado y concentrado, mayor es el grado de masificación de los flujos sociales, pero menor su fuerza política.

La masa siempre ha de mostrar una tendencia creciente para existir y evitar su desintegración (Canetti 1985, p. 11); esta tendencia la conoce bien el capital, que como una masa inhumana tendente a conquistar el todo social también ha de crecer para existir sin desvanecerse. Canetti distingue cinco tipos de masas según el contenido afectivo dominante en ellas (ibidem, p. 43), entre las que cabe resaltar especialmente dos: las masas de inversión y las masas festivas.

1. Las masas de inversión son movidas por el fervor revolucionario, para el capitalismo neoliberal, bien quedó aprendida la lección sobre cómo controlarlas. No hay modo en la historia de prever y evitar una revolución, las masas de inversión no pueden ser anuladas, mas, sí pueden ser controladas mediante la interrupción de su proceso. Canetti da cuenta de cómo antes de la toma de la Bastilla hubo una cacería exacerbada de conejos y liebres, puesto que previamente a la inversión, "que se dirige contra los propios superiores, uno se desquita con los demás de abajo, con los animales de caza" (ibidem, p. 54). El neoliberalismo suspende el proceso de inversión justo en el momento de desquite, perpetúa la ira de los "corderos" reprimidos por sus amos los "lobos" mediante una eufórica cacería de "liebres", pero nunca puede llegar a consumarse la inversión. Las frecuencias de ira no han de llegar a la acción subversiva, más bien, han de atenuarse mediante ataques verbales a los otros; en los países occidentales estos otros, estas "liebres", bien pueden ser inmigrantes procedentes del tercer mundo, Estados "no alineados" sobre los que la "prensa libre" vierte diariamente todo tipo de 
reproches y discursos de odio, el equipo rival y sus aficionados, la feminista reivindicativa, el candidato político contestatario, los "vagos" improductivos que viven a costa de los demás, etc. La contención de las masas de inversión requiere dosificar las frecuencias de ira mediante atenuantes programas de televisión, donde se promueven la inactividad de quienes creen saberlo todo sobre el mundo con solo ponerse frente a una pantalla.

2. Por otra parte, las masas festivas son intensificadas en la dinámica consumista del capitalismo neoliberal, a través de la producción de afectos eufóricos de alta frecuencia. "Las cosas que se exponen y se acumulan ante la vista, y aquellas que se recibe, son una parte esencial de la densidad: su núcleo" (Canetti 1985, p. 57). En una sociedad dirigida por el espectáculo, las mercancías ocupan el centro de atención, pero no porque perduren o potencien la vida, sino porque todo cuanto aparece en el mercado incita la avidez posesiva de cosas nuevas; las cosas mercantilizadas están envueltas en la fugacidad obsolescente que aglutina consumidores. La afluencia masiva de consumidores requiere de fluctuaciones anímicas intermitentes e inconstantes, los afectos por las cosas publicitadas seguirán segmentaciones de corto alcance y, nunca, la posesión o el disfrute de algo resultará tan efímero. Predominancia, por tanto, de todo lo inconstante.

En otro orden de asuntos, conviene poner de relieve cómo para Agamben en la sociedad del espectáculo de Debord el lenguaje opera como generador de espectacularidad (Agamben 2006, p. 66). La comunicación se convierte en herramienta de incomunicabilidad, de modo que "los hombres están separados por aquello que los une. Los periodistas y los mediócratas son el nuevo clero de esta alienación de la naturaleza lingüística" (ibidem, p. 67). Además, cabe añadir que la proliferación a gran escala de las nuevas tecnologías ha contribuido a una mayor optimización en la articulación de comunicaciones y en la transmisión de información; pero el perfeccionamiento tecnológico de las redes no ha cambiado a nivel cualitativo el uso de los medios de comunicación para el dominio de las multitudes. Ya en el siglo XIX, Gabriel Tarde decía que los periódicos producen opinión, la de los grupos privilegiados de la sociedad, imponiendo una temática y unos discursos que interfieren en las conversaciones cotidianas. Los periódicos modelan la opinión en tanto en cuanto son capaces de generar conversaciones (Tarde 1986, p. 87).

Según Tarde, el espíritu colectivo es mucho más volátil que sus componentes por separado, de tal modo que "las imágenes se suceden en él incoherentes, superpuestas o yuxtapuestas sin lazo alguno, como en el cerebro de un hombre dormido o hipnotizado y cada una invade, a su vez, el campo total de la atención" (Tarde 1986, p. 157). La atención es captada por medio de la producción de opinión. A propósito de las aportaciones de Tarde, Lazzarato interpreta de qué forma, para el autor francés, la cooperación entre cerebros en las sociedades civilizadas funciona a través de una coordinación supeditada a "un mecanismo psicológico superior", es decir, que el funcionamiento de las sociedades no es comparable al de un todo orgánico, sino que sus singularidades múltiples fluyen a tenor de operaciones homogeneizadas y centralizadas por un aparato psicológico (Lazzarato 2006, p. 59). 
Lazzarato encuentra que a partir del 11 de septiembre de 2001 las "máquinas de expresión" crean el acontecimiento con el fin de soliviantar la incertidumbre e imprevisibilidad que lo acompaña, todo ello a costa de neutralizar las posibilidades alternativas a las opciones únicas impuestas mediante imágenes y sonidos, transmitidos a través de las máquinas de expresión:

El acontecimiento creado o gestionado por la televisión y los medios no abre ningún posible, sino que constituye el punto de partida de una producción autoritaria del sentido. Apunta a formar un sujeto de enunciación del que van a depender todos los enunciados; a construir un punto de origen de las consignas para la constitución de un público mayoritario y de consenso (Lazzarato 2006, pp. 160-161).

Las sociedades de control escinden a la multitud de su potencia de creación y expresión, anulando todos los "posibles" alternativos; este es el carácter "que toma hoy la expropiación capitalista" (ibidem, p. 161). Si el devenir imprevisible del acontecimiento produce incertidumbre y la esperanza -según la definición de Spinoza- es el afecto que surge ante una expectativa pasada o futura, la potencia creativa del acontecimiento se nutre de las frecuencias afectivas de la esperanza, pero, en un entorno comunicativo dominado por las máquinas de expresión, esas frecuencias son segmentadas en dosis afectivas de euforia en vistas a la reorientación de todas las incertidumbres y expectativas sociales. En las mismas frecuencias afectivas causadas por la posibilidad del acontecimiento se halla también la ira como frustración frente a la imposibilidad de controlar plenamente el acontecer.

Manuel Castells indica que la esperanza y el miedo "se combinan en el proceso político, y los mensajes de las campañas se dirigen a menudo a estimular la esperanza e instilar miedo en el oponente" (Castells 2012, p. 207). Pero Castells está utilizando categorías afectivas primarias en el análisis de las relaciones políticas, unas categorías que el neoliberalismo ha superado y manipulado a su antojo. Cierto que la esperanza y el miedo son las pasiones elementales de la política y que insuflaron los movimientos primarios de las masas en el espacio público; no obstante, la maquinaria de expresión que los medios de comunicación ponen en marcha redefine las fuerzas afectivas de la sociedad para extraer el máximo rendimiento de ellas. Las frecuencias de euforia e ira circulan con mayor grado de inconstancia que la alegría de la esperanza y que la tristeza del miedo.

Las frecuencias emitidas por las máquinas de expresión sintonizan con las frecuencias afectivas de los individuos alterando las primigenias composiciones de afectos inmanentes a las relaciones sociales. La alineación segmentaria de las frecuencias afectivas a las frecuencias emitidas por los artefactos tecnológicos de comunicación e información trastoca las composiciones de afectos originales, produciendo flujos sociales que disminuyen la capacidad subversiva de las fuerzas intrínsecas a la sociedad. Las máquinas de expresión reproducen las frecuencias que habrán de mover los flujos sociales en el espacio de realización de la política y de la economía. 


\section{Conclusiones}

La acumulación de cuerpos movidos por frecuencias eufóricas produce flujos sociales de consumo que resultan de gran interés para la lógica concentracionaria capitalista. La masificación de los flujos de consumo es un fenómeno inducido por el control afectivo sobre la población y, en ningún caso, responde a movimientos espontáneos suscritos a una suerte de preferencias naturales.

Las pasiones se producen en el encuentro de múltiples fluctuaciones del ánimo, lo que implica que las frecuencias afectivas se extiendan como nódulos que atraviesan a la multitud y que su punto originario no coincida con el hermetismo interior de la individualidad. De ahí, la importancia que suscita la dimensión afectivo-subjetiva humana en las prácticas de gobierno y control social. Las masas no adquieren una forma determinada en virtud de operaciones racionales, sino en función de las composiciones afectivas que albergan.

Si el miedo y la esperanza spinozistas son pasiones teológicas, suscritas al sistema de dominación de la monarquía absoluta, la euforia y la ira son la versión actual del régimen económico globalizado. Las segmentaciones de euforia e ira dosifican las frecuencias afectivas de la esperanza y el miedo para reconducir los flujos sociales hacia la concentración masiva de cuerpos humanos, que es el efecto directo del proceso acumulativo y concentracionario de capital.

La ira se filtra entre las multitudes desde fuera de las pautas, límites y márgenes del sistema económico, que trata de promover frecuencias alegres llenas de optimismo infundado; solo así la euforia reemplaza a la esperanza en una interiorización acrítica de discursos dóciles con respecto a la configuración globalista del mundo. Ahora bien, la puerta de entrada de la ira y sus canales de propagación están incluidos en las propias segmentaciones eufóricas, cuyas vacuidades se corresponden con los miedos suscitados por las frustraciones del quehacer económico, miedos que el mercado no subsana y que en las sociedades mercantilizadas solo pueden derivar en ira.

Los movimientos políticos que recurren a frecuencias afectivas de ira para crecer en el espacio público no pueden evitar reproducir la euforia consumista en sus discursos y acciones, de modo que están condenados a desvanecerse en la inconstancia eufórica imperante, dada su incapacidad para practicar una política más allá del slogan, cerrar la brecha de los cortes capitalistas y sustituir la axiomática del capital por códigos que le otorguen plena centralidad a la vida y plena prioridad a las urgencias ecológicas. Por el momento, las nuevas promesas políticas oscilan entre la ira antisistémica exterior al mercado y la euforia impotente y volátil del consumidor.

\section{Referencias bibliográficas}

Agamben, Giorgio (2006), La comunidad que viene. Valencia: Pre-Textos.

Bodei, Remo (1995), Geometría de las pasiones. México: Fondo de Cultura Económica. 
Canetti, Elías (1985), Masa y poder. Barcelona: Muchnik editores.

Castells, Manuel (2012), Comunicación y poder. Madrid: Alianza.

(2017), Ruptura. La crisis de la democracia liberal. Madrid: Alianza.

Cohen, Daniel (2013), Homo economicus. Barcelona: Ariel.

Debord, Guy (2007), La sociedad del espectáculo. Rosario (Argentina): Kolectivo Editorial "Último Recurso".

Deleuze, Gilles; Guattari, Felix (1985), El Anti-Edipo. Barcelona: Paidós.

Deleuze, Gilles (2003), En medio de Spinoza. Buenos Aires: Cactus.

(2006), Spinoza: filosofía práctica. Buenos Aires: Tusquets.

Foucault, Michel (2004), Seguridad, territorio, población. Buenos Aires: Fondo de Cultura Económica.

Han, Byung-Chul (2017), La expulsión de lo distinto. Barcelona: Herder [primera edición digital].

(2012), La sociedad del cansancio. Barcelona: Herder.

Lazzarato, Maurizio (2013a), Gobernar a través de la deuda. Madrid: Amorrortu. (2013b), La fábrica del hombre endeudado. Buenos Aires: Amorrortu. (2006), Por una politica menor. Madrid: Traficantes de Sueños.

Lordon, Frédéric (2015), Capitalismo, deseo y servidumbre. Marx y Spinoza. Buenos Aires: Tinta Limón.

Marcuse, Herbert (1968), El hombre unidimensional. Guaymas (México): Editorial Joaquín Mortiz.

Morfino, Vittorio (2014), El tiempo de la multitud. Madrid: Tierradenadie Ediciones.

Piketty, Thomas (2014), El capital en el siglo XXI. Madrid: Fondo de Cultura Económica.

Sloterdijk, Peter (2010), En el mundo interior del capital. Madrid: Ediciones Siruela. Spinoza, Baruj (2000), Ética demostrada según el orden geométrico. Madrid: Trotta. Tarde, Gabriel (1986), La opinión y la multitud. Madrid: Taurus. 